\title{
Self-selection and socialisation effects of business and legal studies
}

\author{
Tim Rosengart ${ }^{1} \cdot$ Bernhard Hirsch ${ }^{1} \cdot$ Christian Nitzl $^{1}$
}

Published online: 6 March 2020

(c) The Author(s) 2020

\begin{abstract}
To explore the effect of business and legal studies on the resolution of trade-offs between efficiency considerations and fairness concerns, we distributed a survey with three decision cases to freshman and senior business and law students. Our results show that business students, in direct comparison with subjects who study law, make decisions more in accordance with economic theory. Studying business administration leads to decisions that are based more on efficiency criteria, while legal education appears to lead individuals making decisions that are more based on social criteria. Our findings reveal the impact of self-selection and socialization effects on decision making. For business ethics education, this result matters because moral decision making can be influenced during studies.
\end{abstract}

Keywords University education · Self-selection · Socialisation · Economic decision making

JEL Classification A220

\section{Introduction}

Since the turn of the century, several accounting scandals (e.g., WorldCom, Enron), financial fraud offences (e.g., Bernard Madoff), and banking scandals (e.g., the LIBOR and FX market manipulation) have caused severe consequences for companies, business sectors, and societies at large (Gibson et al. 2016). As a result, a public debate on educating future business managers emerged and the decision making

Bernhard Hirsch

bernhard.hirsch@unibw.de

Tim Rosengart

tim.rosengart@law-school.de

Christian Nitzl

christian.nitzl@unibw.de

1 Universität der Bundeswehr München, Werner-Heisenberg-Weg 39, 85577 Neubiberg, Germany 
of business students has often been criticized as selfish and unfair. For example, Floyd et al. (2013) mentioned "the fact that unethical behavior has become almost universal in today's business school environment" (p. 758). Hummel et al. (2018) argued that "[t]heories and ideas taught in economics and business education are claimed to engender moral misbehavior among some managers because these theories mainly focus on the primacy of profit maximization and typically neglect the ethical and moral dimensions of decision making" (p. 560).

Previous studies show mixed results about the impact of academic economics/ business education on decision making. Rubinstein (2006) finds that economics students are "much more pronounced profit-maximizers" (p. C3) than subjects who study mathematics or philosophy, with law students being "somewhere in between" (Rubinstein 2006, p. C4). However, since Rubinstein's research design did not survey respondents at the very beginning or end of their studies, he had to admit his study's "inability to determine clearly whether differences are due to selection bias or are the result of indoctrination" (Rubinstein 2006, p. C8). Cipriani et al. (2009) used survey questions from Rubinstein (2006) and Kahneman et al. (1986a, b) to identify differences in decision making between subjects from different academic backgrounds. To do so, the authors measured decision makers' attitudes towards the market mechanism (Kahneman et al. 1986a) and their preferences for an allocation mechanism (Kahneman et al. 1986b), as well as their profit orientation (Rubinstein 2006). ${ }^{1}$ Regarding business students' choices in the two Kahneman et al. (1986a, b) studies, their economic decision making appears to become more efficient over the course of their education, providing evidence of a socialization effect. The answers that were observed by Cipriani et al. (2009) from freshmen and senior business students with regard to the Rubinstein (2006) questions indicate no change in respondents' answers as a result of a potential socialization effect.

Having analysed the literature with regard to the impact of business education on moral behaviour, it becomes obvious that many contributions measure 'unethical' or unfair behaviour with normative assessments of what is morally good or bad. For example, McCabe et al. (1991, 1994) developed different vignettes to measure the moral quality ("ethical" versus "unethical") of decision making in ethical dilemmas in the fields of personal integrity, coercion, physical environment and conflict of interest, and test cheating. The authors found that significantly more business students decided "unethically" compared to law students. In other contributions (e.g., Fotaki and Prasad 2015), the moral quality of profit maximization or market transactions is also seen critically. Nevertheless, when speaking about 'unethical' or 'unfair' behaviour, it is not always clear what is and what should be meant by this. Kahneman et al. (1986a) already has pointed out, that what is seen as 'fair' is depending on individuals' perceptions of fairness. Nevertheless, in a business decision context fairness is typically associated with an "account for apparent deviations from the simple model of a profit-maximizing" (ibd., p. 728).

\footnotetext{
1 Although the authors surveyed business students at the beginning and end of their studies, they distributed their survey to students from other disciplines (including law students) only at the beginning of their education.
} 
Rubinstein (2006) has already shown that (moral) decision making is highly influenced by the framing of the decision case. Gorman and Kehr (1992) found "that a person's attitude toward the fairness of a business decision is affected by the circumstances surrounding that decision" (p. 357). Previous studies about the moral quality of allocating goods, using market mechanisms or laying off workers have focused on a private-sector environment (e.g., Kahneman et al. 1986a, b; Rubinstein 2006; Goossens and Méon 2015). We analyse three decision scenarios of a city council because in such an environment decisions decision makers are typically confronted with multiple goals which include trade-offs decisions between an efficient use of tax payers' money and serving the society (Rainey et al. 1995; Heinrich 2002). For such a decision context, we analyse if and how efficiency versus fairness considerations are applied and how these decisions are influenced by differences in the university education of the decision makers.

Literature distinguishes between self-selection (Frey et al. 1993) and an education effect (Haucap and Just 2010; Wang et al. 2011) during academic education. We analyse both effects in our research setting, although the latter is particularly relevant for the discussion on "whether economics and business education itself has an impact on students' moral concepts and behaviour and is particularly relevant for the discussion regarding responsible management education" (Hummel et al. 2018, p. 560). We thereby compare decision making behaviour of business students with the behaviour of law students. We focus on these groups because it is typically for business managers and for law graduates to be responsible for personnel and for making investment decisions; in both areas efficiency and fairness aspects have to be considered. $^{2}$

Following the example of earlier studies (e.g. Goossens and Méon 2015; Cipriani et al. 2009) we use three decision cases that were originally developed by Kahneman et al. (1986a, b) and Rubinstein (2006) as a basis for our analysis. As already mentioned, we transferred the cases scenarios to a city council environment because decision makers in public administrations are a good example for a group of subjects regularly confronted with trade-offs between social needs and economic efficiency (Kreisverwaltungsreferat der Landeshauptstadt München 2010; Personal- und Organisationsreferat der Landeshauptstadt München 2014; Sozialreferat der Landeshauptstadt München 2014). Consistent with our predictions, we find for our setting that law students make decisions that are not in accordance with economic theory in the beginning and phase of their studies. Legal education seems to lead law students making decisions based on fairness criteria, while studying business administration leads business students to make decisions based more on efficiency criteria.

The contribution of our study is threefold. First, our results show the relevance of university education on ethical decision making based on a dataset that systematically includes freshman and senior students of business and law. Second, our study provides empirical evidence that a self-selection effect exists for business and law

\footnotetext{
${ }^{2}$ Although law students are trained during their studies to work for the government or other public institutions, many of them-similar to business students-plan a career in the private industry. See therefore e.g. Wolff (2017).
} 
Table 1 The defining characteristics of legal and business studies. Source: similar to Rosengart et al. 2019, p. 459

\begin{tabular}{ll}
\hline Legal studies & Business studies \\
\hline $\begin{array}{c}\text { Objectives, content, structure and final examina- } \\
\text { tions are typically defined by laws and are highly } \\
\text { standardized }\end{array}$ & No legal standards \\
$\begin{array}{c}\text { Focus on preparing students for traditional legal } \\
\text { careers in the judiciary (judges/prosecutors), law } \\
\text { firms (lawyers) and the public administration }\end{array}$ & $\begin{array}{c}\text { Focus on preparing students for jobs in firms, which } \\
\text { must compete in a market economy } \\
\text { Typically no focus on a career in the public adminis- } \\
\text { tration }\end{array}$ \\
$\begin{array}{c}\text { Students are taught to apply legal texts form a } \\
\text { judge's point of view; all legal texts are chosen } \\
\text { by legislation }\end{array}$ & $\begin{array}{c}\text { Students are taught how to make efficient decisions } \\
\text { under conditions of scarcity }\end{array}$ \\
$\begin{array}{c}\text { Little to no introduction to microeconomic theory } \\
\text { and the concept of economic efficiency }\end{array}$ & $\begin{array}{c}\text { Students are taught skills and knowledge that are } \\
\text { correct from the viewpoint of microeconomic } \\
\text { theory }\end{array}$ \\
$\begin{array}{c}\text { No obligatory (business) ethics courses, but focus } \\
\text { on fairness in a sense of promoting social justice }\end{array}$ & \begin{tabular}{c} 
Mostly no obligatory business ethics courses \\
\hline
\end{tabular}
\end{tabular}

freshmen that was created before starting their university education. Third, we can show a socialization effect during university studies for a decision context with a specific fairness setting. Our findings indicate that university education does have an impact on decision making in moral-sensitive settings.

The remainder of our paper is structured as follows. Section 2 reviews the key characteristics of legal and business education. Subsequently, our research hypotheses are conceptualized in Sect. 3, referencing existing empirical studies. Section 4 describes the research method, the dataset and the results of the study at hand. Finally, Sect. 5 discusses the contribution of our empirical findings to the existing literature.

\section{Business and law education at universities}

During their studies, law students are mainly prepared for traditional legal careers in the judiciary (e.g. judges/prosecutors; lawyers; the public administration). Students learn skills that they need to resolve problems that require a trade of between different parties' interests; thereby they have to decide what is fair and what is not. During their education they are also confronted with the basic principles of governance. In this context, the promotion of a social state and the creation and maintenance of social justice can be interpreted as important elements of a specific understanding of fairness. Their academic discipline teaches them also strong social skills (e.g. argumentation; interviewing; negotiation) but it neglects to acquaint its students with microeconomic theory and/or the concept of economic efficiency (Rosengart et al. 2019; Korioth 2006). 
In contrast with legal education, business education faces much less regulation (see also Table 1). ${ }^{3}$ However, the examination and study policies for business studies have in common that business faculties focus on teaching their students the efficient use of resources and prepare them for jobs in which they must compete in a market economy (compare, e.g., Ludwig-Maximilians-Universität München 2016; Freie Universität Berlin 2012). In addition to subjects such as finance, accounting and marketing, most curricula contain obligatory courses in microeconomics. Business ethics courses are generally not obligatory in most business programmes and most universities "generally do not offer an educational environment in which optimal moral development can occur" (Hummel et al. 2018, p. 561).

Microeconomics textbooks commonly describe their objective as helping students to develop an economic intuition and encouraging their readers to develop the distinctive mind-set known as "thinking like an economist" (Frank 2013, p. vii). Economists are expected to make economically efficient choices that result from "the direct comparison of the advantages [benefits] and disadvantages [costs] of several alternatives in the set of possible choices [scarcity]" (Lanteri and Rizzello 2009, p. 902). Similarly, efficient choices are expected to be unaffected by any form of altruism, as the non-fairness assumption of economics "expresses a resistance to explanations of economic actions in moral terms" and assumes "the common good to be well served by the free actions of self-interested agents in a market" (Kahneman et al. 1986b, p. 286). The previous definition of what constitutes economically efficient decision making from the perspective of microeconomic theory can be applied to any economic problem and also any decision in a public sector context.

\section{Conceptual framework and hypotheses}

\subsection{Self-selection as a reason for the different decision making of law and business freshmen}

Holland (1997) argues that individuals make decisions that fit them, where 'fit' means a congruence between their personal characteristics and the particularities of the academic discipline that they self-select into. Individuals would strive for congruence with their respective environments because, in these situations, job satisfaction or educational satisfaction is highest and individual utility will be maximized (Holland 1997; Spokane 1996; Wilkins and Tracey 2014). To achieve their objectives, individuals search for meaningful tasks that allow them to use previously acquired skills and knowledge as well as the expression of their personal values (Holland 1997; Nauta 2013).

Prospective students are expected to act rationally with regard to their educational choices (Holland 1997; Brown and Brooks 1996; Porter et al. 1975). Taking this argument into account, and considering that individuals invest large amounts of time and money into their studies, it can be assumed that individuals have properly

\footnotetext{
3 The empirical findings of Goossens and Méon (2010) and Rubinstein (2006) suggested that no distortions should be expected from focusing on subjects who studied business instead of economics.
} 
informed themselves through the available information (e.g., brochures, websites, events) about the key characteristics of the educational programmes that they selfselect themselves into (Hambrick and Mason 1984).

Reflecting the key characteristics of legal and business studies (Table 1) and following the previous line of argument that subjects who self-select into legal or business studies on purpose and with the intention of maximizing their personal utility, leads us to the expectation that subjects who self-select into legal studies are less likely to make decisions in accordance with economic theory than subjects who selfselect into business studies. Therefore, we assume the following:

H1: Freshman business studies decide more in accordance with economic theory than freshman law students.

\subsection{Socialization during legal and business studies}

During their university education, individuals have two motives for socialization. On the one hand, individuals' internal willingness to socialize reflects their efforts to increase their personal congruence with the particularities of a newly joined group. On the other hand, the external pressure to socialize describes the attempts of social entities to integrate their new members. Both motives have in common that they relate to subjects' ambitions to maximize their own utility (Lüthje 2008; Katz 2004; Schein 2003).

Universities exercise external pressure on their students to encourage them to strive for their own socialization. The means by which universities can exercise pressure on their students include, for example, confronting them with large workloads, difficult exams and high dropout rates or the strict enforcement of rules. The reason why many universities exercise strong external pressure on their students is explained by the fact that, if they succeed in their task, they are rewarded with benefits (e.g., good reputation, additional research funding) (Ashforth et al. 2007; Gruman et al. 2006; Allen 2006; Saks and Ashforth 1997; Allen and Meyer 1990; Jones 1986; Pascale 1985).

Individuals' internal willingness to socialize is correlated with their intention to avoid any form of cognitive dissonance with other members of their social entity (i.e., fellow students, professors) (Lüthje 2008; Schein 2003). Law and business students can only avoid cognitive dissonances with their respective disciplines when they adapt their cognitive base and values to those of other individuals in their group. Such adaptations may occur through the acquisition of the relevant skills and knowledge of their respective academic disciplines through practice and learning (Lüthje 2008; Frey et al. 2001; Pfeffer 1997; Festinger 1957).

Taking into account the skills and knowledge that are taught during legal and business studies (Table 1), one can assume that law students decide less in line, and business students more in line with economic theory. The effect of socialisation is expected to grow over time. Therefore, we assume:

$\mathrm{H} 2$ : Senior law students decide less in line with economic theory than freshmen law students. 
H3: Senior business students decide more in line with economic theory than freshmen business students.

H4: Senior business students decide more in line with economic theory than senior law students.

\section{Data and methodology}

The operationalization of our research hypotheses focuses on measuring subjects' decision making in situations that require a trade-off between fairness concerns and economic efficiency. We use vignettes to test the decision-making behaviours of our sample. Vignettes are "short descriptions of a person or social situation that contain precise references to what are thought to be the most important factors in the decision-making or judgment-making processes of respondents" (Alexander and Becker 1978, p. 94). In our setting, we focus on the impact of education on financial decision making; this variable was not changed across the three decision cases because it is directly linked to the participants' personalities. Vignette (quasi-) experiments are characterized as being appropriate for analysing the influence of a social context on individual decisions and behaviours (Kunz and Linder 2012; Taylor 2006). Vignettes allow for the examination of personal aspects that are otherwise not directly observable (Kunz and Linder 2012). In our case, the influence of education and the impact of the organizational environment in which the individuals are embedded can be analysed. Using a withinsubjects design, we confront all the participants with three decision cases. This approach allows us to collect data about decision making from all the participants in three different situations (Wallander 2009, p. 506; Taylor 2006, p. 1197) and to test their decision-making behaviours according to fairness/equity vs. efficiency issues (similar Walker et al. 2013).

In line with Rosengart et al. (2019), we use three cases which were originally developed by Kahneman et al. (1986a, b) and Rubinstein (2006) as a basis to test our hypotheses. All three cases were adapted to a setting business and law students should be familiar with. The decision case from Kahneman et al. (1986a) allows us to measure decision makers' perceived fairness of the market mechanism ('market case'). Similarly, the decision case from Kahneman et al. (1986b) appears to be a reliable measure of individuals' preferences for specific resource allocation mechanisms ('allocation case'). For creating this measurement, we focus on the first choice. The most perceived fair choice (what is exactly in contrast to what economic theory would say is the most efficient choice) is the queue (1), followed by the lottery (2), and finally the allocation choice (3). Both decision cases are similar because the respondents must weigh their pro-market orientation against social concerns (i.e., fairness). Our third decision case was taken from Rubinstein (2006) because it can measure decision makers' preferences for profit maximization regarding direct conflict between company objectives and workers' welfare ('profit case'). For creating this measurement, we ranked the 
Table 2 Dataset for the empirical analysis

\begin{tabular}{llll}
\hline Sample & Abbreviation & Sample size & $\begin{array}{c}\text { \% of overall } \\
\text { population }\end{array}$ \\
\hline First semester law students & $(=$ Freshmen Law-FL) & 424 & 56 \\
Fifth semester law students & $(=$ Seniors Law-SL) & 115 & 23 \\
First semester business students & (=Freshmen Business-FB) & 448 & 85 \\
Fifth semester business students & $(=$ Seniors Business-SB) & 246 & 76 \\
Total & & 1233 & \\
\hline
\end{tabular}

choices according the profit. The adjusted decision cases (Rosengart et al. 2019) are displayed in the appendix (Tables $5,6,7$ ) of this text.

In line with Lüthje (2008), Cipriani et al. (2009), Brosig et al. (2010) and Rosengart et al. (2019), we use a questionnaire design that incorporates our decision cases to generate a dataset that allows us to empirically test the research hypotheses of this study. To control for externalities and to increase the comparability of our student samples, we decided to distribute our questionnaire only among students from the faculties of law and business of one German university with a long history in teaching law but also business administration. ${ }^{4}$ Senior students were surveyed at the beginning of the fifth semester because it represented the last chance to survey the maximum number of individuals before students from both disciplines must specialize in selected areas of their academic discipline (e.g., criminal law; finance). To achieve the maximum level of participation across student populations, an author of this study appeared during lectures by selected professors, read aloud a standardized welcome note that focused on organizational matters and the anonymity of participants' answers, and, then, together with the lecturer, distributed the questionnaire to the class. Respondents from our four populations required $17 \mathrm{~min}$, on average, to complete the questionnaire, which, after completion, had to be dropped anonymously into boxes located next to the doors of the students' classroom. Table 2 illustrates the sample size for each of the four populations that completed our questionnaire.

Table 2 also shows the percentage share of the entire population that completed our questionnaire. ${ }^{5}$ The overall population (at the university where we performed the study) refers to official data provided via email by the staff of the university where we performed our study. The calculations are based on the official numbers of students who were studying in the winter semester of October 2012, either law (first semester: 758/fifth semester: 496) or business administration (528/324). Furthermore, of the 1233 participants $46.9 \%$ are women and $53.1 \%$ are men.

\footnotetext{
${ }^{4}$ We used the same student sample as in Rosengart et al. (2019).

5 In 2012 almost 103,000 young men and women were studying law in Germany while almost 209.000 young men and women studied Business Administration (Sources: Statistisches Bundesamt 2019/Statista 2019). Of course, we were not able to ask all of them to participate in our study. We therefore decided to ask law and business students of one of the biggest state-owned university in Germany to participate in our study.
} 
Fig. 1 Summary of the research hypotheses and required dataset
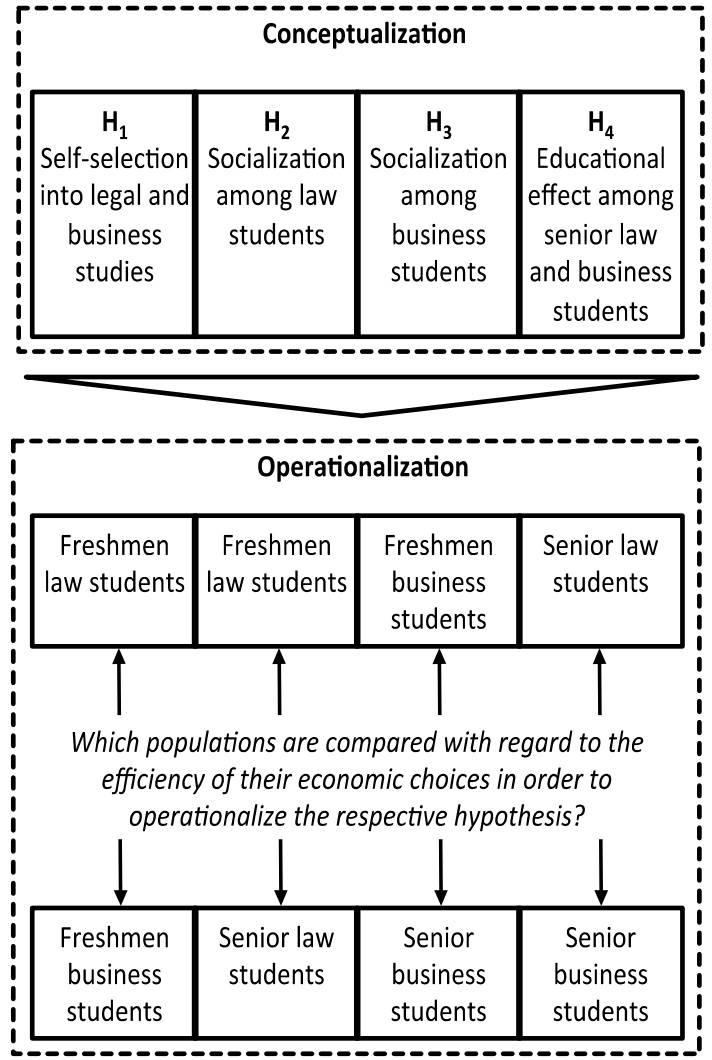

Figure 1 summarizes which samples must be compared to operationalize our research hypotheses. Research hypothesis H1 expects that subjects who self-select into business studies decide more in line with economic theory than subjects who self-select into legal studies. To test H1, the efficiency of business and law students' decisions in our three decision cases must be compared based on their efficiency at the very beginning of their respective studies (Cipriani et al. 2009; Haucap and Just 2003; Frey et al. 1993). Our second and third research hypotheses propose that socialization effects influence individuals' economic choices over the course of their studies. To test $\mathrm{H} 2$ and $\mathrm{H} 3$, the decisions of freshmen law students must be compared to those of senior law students, while the decisions of freshmen and senior business students must be compared within their discipline. Our last research hypothesis proposes that differences exist among subjects who graduate from business studies and subjects who graduate from legal studies. To test H4, business and law students must be compared at the end of their educations regarding their decisions in our three decision-making cases.

We use a partial least squares factorial structural equation modelling (PLS FAC-SEM) approach for the analysis of the data, which is a specific form of PLSSEM (Hair et al. 2017). In our case, the factors are the different samples, and the 
Table 3 Descriptive statistics

Market case (similar to Kahneman et al. 1986a) ${ }^{\text {a }}$

\begin{tabular}{|c|c|c|c|c|c|c|c|}
\hline & \multicolumn{2}{|r|}{1} & \multicolumn{2}{|c|}{2} & \multicolumn{2}{|l|}{3} & 4 \\
\hline Freshman law (FL) (\%) & \multicolumn{2}{|r|}{6.86} & \multicolumn{2}{|c|}{45.39} & \multicolumn{2}{|c|}{39.48} & 8.27 \\
\hline Freshman business (FB) (\%) & \multicolumn{2}{|r|}{7.62} & \multicolumn{2}{|c|}{30.94} & \multicolumn{2}{|c|}{50.00} & 11.43 \\
\hline Senior law (SL) (\%) & \multicolumn{2}{|r|}{36.61} & \multicolumn{2}{|c|}{44.64} & \multicolumn{2}{|c|}{13.39} & 5.36 \\
\hline Senior business (SB) (\%) & \multicolumn{2}{|r|}{7.72} & \multicolumn{2}{|c|}{34.96} & \multicolumn{2}{|c|}{49.59} & 7.72 \\
\hline \multicolumn{8}{|c|}{ Allocation case (similar to Kahneman et al. 1986b) } \\
\hline & \multicolumn{3}{|c|}{1} & \multicolumn{3}{|c|}{2} & 3 \\
\hline Freshman law (FL) $(\%)$ & \multicolumn{3}{|c|}{18.48} & \multicolumn{3}{|c|}{51.42} & 30.09 \\
\hline Freshman business (FB) (\%) & \multicolumn{3}{|c|}{21.77} & \multicolumn{3}{|c|}{34.47} & 43.76 \\
\hline Senior law (SL) (\%) & \multicolumn{3}{|c|}{28.97} & \multicolumn{3}{|c|}{50.47} & 20.56 \\
\hline Senior business (SB) (\%) & \multicolumn{3}{|c|}{13.28} & \multicolumn{3}{|c|}{25.31} & 61.41 \\
\hline \multicolumn{8}{|c|}{ Profit case (similar to Rubinstein 2006) ${ }^{c}$} \\
\hline & 1 & 2 & 3 & 4 & 5 & 6 & 7 \\
\hline Freshman law (FL) (\%) & 0.99 & 23.21 & 0.00 & 24.69 & 0.99 & 27.41 & 22.72 \\
\hline Freshman business (FB) (\%) & 1.60 & 20.82 & 0.00 & 20.82 & 0.00 & 24.03 & 32.72 \\
\hline Senior law (SL) $(\%)$ & 1.80 & 32.43 & 0.00 & 27.93 & 0.90 & 20.72 & 16.22 \\
\hline Senior business (SB) (\%) & 0.87 & 22.71 & 0.00 & 17.90 & 0.00 & 18.78 & 39.74 \\
\hline
\end{tabular}

${ }^{\mathrm{a}} 1=$ very unfair; $2=$ unfair; $3=$ acceptable; $4=$ completely fair

${ }^{\mathrm{b}} 1$ = queue; 2 = lottery; 3 = auction

${ }^{\mathrm{c}} 1=$ loss of 8.0 (all workers will be laid off); $2=$ profit of 0.4 (no layoffs); $3=$ profit of 1.0 (146 workers will be laid off); $4=$ profit of 1.0 (26 workers will be laid off); $5=$ profit of 1.5 (131 workers will be laid off); $6=$ profit of 1.6 (52 workers will be laid off); $7=$ profit of 2.0 (96 workers will be laid off)

dependent variables are the responses to the three cases. This approach allows us to assess whether and how model relationships vary as a function of an underlying factorial design (Streukens and Leroi-Werelds 2016). The advantage of using this approach, in contrast to a regression analysis, is that it is possible to simultaneously test the influence of the groups on all three cases in a single model (Nitzl 2016, 2018). The reported path coefficients can be interpreted in the same manner as the standardized coefficients in a regression analysis. Moreover, it is also possible to control our results for the effect of sex. To test the influence of the different groups, we used 5.000 accelerated bias-corrected bootstraps. This enables distribution-free significance tests (Wood 2005). 
Table 4 Path coefficients (first line) and p-values (second line)

\begin{tabular}{lccc}
\hline & "Market case" & "Allocation case" & "Profit case" \\
\hline H1 & $\mathbf{0 . 0 6 2}$ & 0.040 & $\mathbf{0 . 0 8 1}$ \\
& 0.032 & 0.110 & 0.005 \\
H2 & $\mathbf{- 0 . 0 6 2}$ & -0.009 & $-\mathbf{0 . 0 7 8}$ \\
& 0.020 & 0.375 & 0.005 \\
H3 & 0.012 & $\mathbf{0 . 1 5 1}$ & -0.034 \\
& 0.360 & 0.000 & 0.140 \\
H4 & $\mathbf{0 . 1 0 3}$ & $\mathbf{0 . 1 9 7}$ & $\mathbf{0 . 1 8 7}$ \\
& 0.015 & 0.000 & 0.000 \\
Control "sex" & $\mathbf{- 0 . 1 2 3}$ & $\mathbf{0 . 1 1 8}$ & $-\mathbf{0 . 0 8 8}$ \\
& 0.000 & 0.000 & 0.002 \\
\hline
\end{tabular}

\section{Results}

Table 3 displays the descriptive statistics for the three cases in this study. Especially the "profit case" illustrates the validity of the answers. For example, nearly no student has chosen the first answer (Loss of 8/"all workers will be laid off') which means the highest loss for the municipal service provider and also the highest amount of workers' lay off. The answers "profit of 1.0/146 workers will be laid off" as well as profit of 1.5/"131 workers will be laid off" are also inferior to other answers; again nearly no student has chosen these answers. This results in a quite non-normal distribution of answers. However, because we use a bootstrapping approach for the following inference statistic, this does not harm our analysis (Hair et al. 2020).

Table 4 presents the results of the hypothesis testing. The first lines show the path coefficients and the second lines indicate the p-values of two-tailed tests based on the bootstrapping results. Significant path coefficients are shown in bold.

Hypothesis H1 proposes that subjects who self-select into business studies would make decision that are more economically correct than those of subjects who self-select into legal studies. The assumption of the first research hypothesis (H1) is correct with regard to the decisions that were observed from freshmen business students and freshmen law students in the profit case and the market case $(0.081 ; p=0.005 ; 0.062 ; p=0.032)$. No significant differences were found between the freshmen's preferences for specific mechanisms to allocate scarce resources (allocation case) $(0.040 ; \mathrm{p}=0.110)$.

Research hypothesis $\mathrm{H} 2$ assumes that the economic choices of law students are less in line with economic theory as a consequence of their socialization, while $\mathrm{H} 3$ expects that the decisions of business students become more in line with economic theory as a result of their studies. According to the empirical evidence that was found, we can show that, for the "market case" $(-0.062 ; p=0.020)$ and the "profit case" $(-0.078 ; \mathrm{p}=0.005)$, the economic decision making of law students became less consistent with economic theory. The assumption of hypothesis H3, in contrast, is correct with regard to business students' preferences for a specific 
mechanism for allocating scarce resources $(0.151 ; \mathrm{p}=0.000)$. No significant differences were observed between the answers of freshmen and senior business students in the context of the other survey questions.

Hypothesis $\mathrm{H} 4$ proposes that subjects who graduate from business studies decide more in line with economic theory compared to subjects who graduate from legal studies. Significant differences were found between senior business students and senior law students with regard to their preferences for profit orientation $(0.103 ; \mathrm{p}=0.015)$, their preference for a mechanism to allocate scarce resources $(0.197 ; p=0.000)$, and their profit orientation $(0.187 ; p=0.000)$. In all the cases, business graduates made decisions that were more in line with economic theory compared to those of subjects who graduated from legal studies.

We also control our results for the effect of "sex". We found that, for both the "market case" $(-0.123 ; \mathrm{p}=0.000)$ and the "profit case" $(-0.103 ; \mathrm{p}=0.014)$, women's decisions are significantly less in line with economic theory. In contrast, for the "allocation case" $(0.118 ; \mathrm{p}=0.000)$, women's decisions are more in line with economic theory.

\section{Discussion and conclusions}

We observe significant differences between the decisions of freshmen students with regard to their choices in the allocation of scarce goods and their preferences for profit maximization in light of direct conflict between efficiency goals and workers' welfare. Because we surveyed our freshmen student sample groups during their very first week at university, exposure to their academic disciplines cannot be blamed for differences between their cognitive bases and values (i.e., their givens). Differences must be attributed to differences between respondents' givens that existed prior to the start of their studies. Because German secondary education usually does not include the economic concepts that were involved in the operationalization of the research hypotheses, the respondents' personal values are particularly important (Guiso et al. 2006; Hambrick and Mason 1984). According to the previous discussion, it is more than likely that personal values have an impact on significantly different decision making behaviour between freshmen law students and freshmen business students which was found with regard to the "market case" and the "profit case" but not in the context of the "allocation case". In this context, it is important to mention that the survey questions of the market case and the profit case appeal to respondents' personal values much more than the survey questions of the allocation case because the latter survey questions confront decision makers with the morally difficult task of finding an allocation mechanism for public land. By contrast, the other two survey questions seem to be clearer from a moral point of view. Another explanation could be that school graduates are not intuitively familiar with the mechanism and the moral impact of the allocation mechanism.

Our empirical results confirm $\mathrm{H} 2$ for the market and profit case. Therefore, in both cases, senior law students made decisions that were less in accordance with 
economic logic than those of law freshman. This finding indicates that law students become socialized with the idea of fairness during their studies. For the allocation case, we find evidence that the options from which our respondents could choose were not in direct conflict with the legal texts and models that law students had learned to apply during their studies.

It was previously argued that the education of business students is heavily influenced by models that focus on teaching students how to make efficient choices under conditions of scarcity. Furthermore, business students learn how to make decisions that are in line with microeconomic theory. In this context, we can assume that business students are taught the mechanism of allocating scarce resources. As senior students, they are much more familiar with the different allocation methods and their economic consequences compared to business freshman. Therefore, it seems plausible that, with regard to the allocation case, the decisions of the business students were observed to become significantly more in line with economic logic during their studies. The students even applied the auction rule (which is the most efficient allocation mechanism) to a public sector context. Such behaviour could provide further evidence in support of the relevance of university education on decision makers' values (Hambrick and Mason 1984; Guiso et al. 2006). We can even argue that the socialization of business students provides them with guidance in deciding a morally relevant case ("who gets public land and at which price?"). The non-significance of the socialization effect for the profit and market cases can be explained by the fact that the business freshmen already used the market and price mechanisms at the start of their studies and therefore do not change their decision behaviour over time.

Our findings with regard to H3 support the findings of Haucap and Just (2003) who found evidence for a socialization effect and contradict those of Goossens and Méon (2010) who had found no evidence for such an effect. The findings of Cipriani et al. (2009) are similar to ours with regard to the allocation case, as they found that business students' preferences for a mechanism for allocating scarce resources became more efficient over the course of their studies. With regard to subjects' profit orientations in the profit case, like us, Cipriani et al. (2009) did not find evidence of a socialization effect that impacts the choices of business students over the course of their studies. Contrary to Hummel et al. (2018) who found "neither a self-selection nor a treatment effect for economics and business students" (p. 559), our findings partly show a self-selection and socialization effect of university studies.

We found empirical evidence in support of research hypothesis $\mathrm{H} 4$ which shows that senior business students and senior law students significantly differ with regard to their decisions in the market case, the allocation case, and the profit case. In all three cases, senior business students made decisions that were more in line with economic theory compared to senior law students. These findings confirm a significant socialization effect among law and business students for our context. Considering the existing empirical literature, our empirical findings demonstrate that the degree, to which the self-selection and socialization effects appear, seems to depend on the survey question that is used for measuring respondents' decision making: Socialization effects among business students explain the differences in the decision making 
of senior business and senior law students for the allocation case. The effect of selfselection is mainly responsible for the market and the profit case.

Our results contribute to the business education literature by indicating that decisions in a context that are not always clear from a moral point of view (McCabe et al. 1991), are significantly influenced by self-selection effects and by the university education of the decision maker.

Our findings also have relevance for business education: First, we see a socialization effect when comparing the decision making of senior business and senior law students. Such an effect is significant for each of the three cases. For the allocation case in particular, the assessment of the three allocation rules (auction, lottery or first-come, first-served basis) seems to be unclear for business students and changes over the course of their studies. In contrast, law students are at least implicitly socialized during their studies about the consequences of using the market and the price mechanism and use them less at the end of their studies. Therefore, university education matters and business education could influence future decision making.

Of course, this study does not come without limitations. First, social desirability might have distorted our empirical results. In this context, Raab-Steiner and Benesch (2018) argue that there is a danger that respondents do not state their real opinions but provide answers that are in accordance with social norms. Second, although our sample groups should represent their overall populations relatively well, generalizations from our findings must be drawn with caution because our previous discussion is based on the economic choices that were observed from students at one university. Past research by Kahneman et al. (1986a), Gorman and Kehr (1992), Haucap and Just (2010) and Faravelli (2007) has shown that the framing of survey questions has a greater influence on respondents' decisions than the background characteristics of their samples (i.e. control variables). In this context, it is important to recapitulate that this study is the first to modify the survey questions of Kahneman et al. (1986a, b) and Rubinstein (2006). Therefore, it is possible that framing our survey questions could have had an impact on the economic choices of our respondents and may explain deviations from the answers that were observed by previous studies which focused entirely on a private sector context.

Although the empirical results of the pre-tests and the final survey make us confident that we have successfully avoided large distortions from the translation and modification of the original survey questions, we appreciate future research that challenges our findings on comparable empirical grounds.

\section{Acknowledgements Open Access funding provided by Projekt DEAL.}

Open Access This article is licensed under a Creative Commons Attribution 4.0 International License, which permits use, sharing, adaptation, distribution and reproduction in any medium or format, as long as you give appropriate credit to the original author(s) and the source, provide a link to the Creative Commons licence, and indicate if changes were made. The images or other third party material in this article are included in the article's Creative Commons licence, unless indicated otherwise in a credit line to the material. If material is not included in the article's Creative Commons licence and your intended use is not permitted by statutory regulation or exceeds the permitted use, you will need to obtain permission directly from the copyright holder. To view a copy of this licence, visit http://creativecommons.org/licen ses/by/4.0/. 


\section{Appendix}

\section{See Tables 5, 6, 7.}

Table 5 Adjustments to the original version of the Kahneman et al. (1986a) survey question based on a real decision by the Kreisverwaltungsreferat der Landeshauptstadt München (2010); Source: Rosengart et al. (2019, p. 473)

\begin{tabular}{|c|c|}
\hline $\begin{array}{l}\text { Original version of the survey question of Kahne- } \\
\text { man et al. (1986a) }\end{array}$ & $\begin{array}{l}\text { Modified version of the survey question that was } \\
\text { used in the survey for this study }\end{array}$ \\
\hline $\begin{array}{l}\text { "A hardware store has been selling snow shovels } \\
\text { for } \$ 15 \text {. The morning after a large snowstorm, } \\
\text { the store raises the price to } \$ 20 \text {. } \\
\text { Please rate this action as: } \\
\text { Completely fair, acceptable, unfair, or very } \\
\text { unfair". }\end{array}$ & $\begin{array}{l}\text { A city owns a carpark that is located right next to a } \\
\text { congress hall. The city does not manage the park- } \\
\text { ing garage by itself but relies on the services of } \\
\text { a private firm. The contract between the city and } \\
\text { the management of the carpark stipulates that the } \\
\text { municipal council must approve all adjustments } \\
\text { to the fee that it charges its users. At present, } \\
\text { the parking fee is set at } 15 \text { Euros per day. In the } \\
\text { upcoming week, a major event takes place in the } \\
\text { congress hall. The management of the car park } \\
\text { proposes to raise the fee from } 15 € \text { to } 20 € \text { during } \\
\text { the event. } \\
\text { Please assume the role of a senior official who faces } \\
\text { the task of advising the municipal counsel on a } \\
\text { temporary adjustment of the fee for a parking } \\
\text { garage and rate this action as: } \\
\text { Completely fair, acceptable, unfair, or very unfair. }\end{array}$ \\
\hline
\end{tabular}

Table 6 Adjustments to the original version of the Kahneman et al. (1986b) survey question based on a real decision by the Personal- und Organisationsreferat der Landeshauptstadt München (2014); Source: Rosengart et al. (2019, p. 473)

\begin{tabular}{|c|c|}
\hline $\begin{array}{l}\text { Original version of the survey question of Kahne- } \\
\text { man et al. (1986b) }\end{array}$ & $\begin{array}{l}\text { Modified version of the survey question that was } \\
\text { used in the survey for this study }\end{array}$ \\
\hline $\begin{array}{l}\text { "A football team normally sells some tickets on } \\
\text { the day of their games. Recently, interest in the } \\
\text { next game has increased greatly, and tickets are } \\
\text { in great demand. The team owners can distribute } \\
\text { the tickets in one of three ways. (1) By auction: } \\
\text { the tickets are sold to the highest bidders. (2) By } \\
\text { lottery: the tickets are sold to the people whose } \\
\text { names are drawn. (3) By queue: the tickets are } \\
\text { sold on a first-come first-served basis. } \\
\text { Rank these three in terms of which you feel is the } \\
\text { most fair and which is the least fair-the auc- } \\
\text { tion, the lottery, and the queue". }\end{array}$ & $\begin{array}{l}\text { A city wants to sell land that can be used as con- } \\
\text { struction sites. It announces that } 50 \% \text { of the avail- } \\
\text { able land will be sold to long-term residents, while } \\
\text { the remainder is offered to any interested party. } \\
\text { Upon announcement of this news, the demand for } \\
\text { the construction sites is much greater than the } \\
\text { available supply. } \\
\text { The municipal counsel discusses three resource allo- } \\
\text { cation mechanisms by which it could distribute } \\
\text { the scarce construction sites. (1) By auction: the } \\
\text { construction sites are sold to the highest bidders. } \\
\text { (2) By lottery: the construction sites are sold to } \\
\text { the people whose names are drawn first. (3) By } \\
\text { queue: the tickets are sold on a first-come, first- } \\
\text { served basis. } \\
\text { Please assume the role of a senior official who faces } \\
\text { the task of advising the municipal counsel on the } \\
\text { sale of the limited construction sites. Rank the } \\
\text { aforementioned allocation mechanisms in terms } \\
\text { of which you feel is the most fair and which is the } \\
\text { least fair. }\end{array}$ \\
\hline
\end{tabular}


Table 7 Adjustments to the original version of the Rubinstein (2006) survey question based on a real decision by the Sozialreferat der Landeshauptstadt München (2014); Source: Rosengart et al. (2019, p. 474)

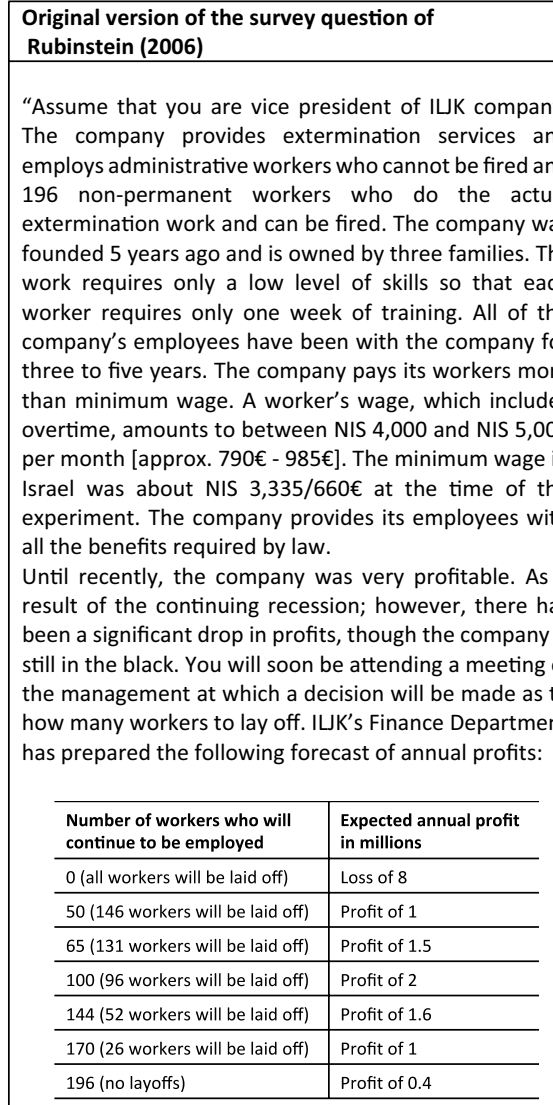

I will recommend continuing to employ of the 196 workers in the company".

\section{Modified version of the survey question that was used} in the survey for this study

Assume that you are a senior official in your hometown. As part of your position, you are responsible for the municipal service provider of your city. The workforce of the municipal service provider is in charge of many different tasks, which range from garbage collection to the supply of fresh water and include the management of the theatre and swimming pool in your community. The municipal service provider employs administrative specialists who cannot be fired and 196 non-permanent workers with fixed-term contracts. The tasks of the employees with fixed-term contracts require only a low level of skills such that each worker requires only one week of training. All of the employees of the municipal service provider have been working for your city for three to five years. The city pays its non-permanent employees a salary that is in accordance with the collective agreement that applies to all workers who are employed by the authorities of the state in which your town is located. Furthermore, your city provides its employees with all the benefits required by law.

As a result of an economic recession, the profits of the municipal service provider have deteriorated. This development, in turn, has had a negative impact on the budget of your city. The municipal counsel discusses an opportunity to save money through a reduction in the non-permanent workers who are employed by the municipal service provider. You will soon be attending a meeting of the municipal counsel at which a decision will be made regarding the number of workers to lay off. The finance department of your city prepared the following forecast:

\begin{tabular}{l|l}
\hline $\begin{array}{l}\text { Number of workers who will } \\
\text { continue to be employed }\end{array}$ & $\begin{array}{l}\text { Expected annual profit } \\
\text { in millions }\end{array}$ \\
\hline 0 (all workers will be laid off) & Loss of 8 \\
\hline 50 (146 workers will be laid off) & Profit of 1 \\
\hline 65 (131 workers will be laid off) & Profit of 1.5 \\
\hline 100 (96 workers will be laid off) & Profit of 2 \\
\hline 144 ( 52 workers will be laid off) & Profit of 1.6 \\
\hline 170 (26 workers will be laid off) & Profit of 1 \\
\hline 196 (no layoffs) & Profit of 0.4 \\
\hline
\end{tabular}

I will recommend that the municipal counsel continue to employ of the 196 workers who currently work for the municipal service provider.

\section{References}

Alexander CS, Becker HJ (1978) The use of vignettes in survey research. Public Opin Q 42(1):93-104 Allen DG (2006) Do organizational socialization tactics influence newcomer embeddedness and turnover? J Manag 32(2):237-256

Allen NJ, Meyer JP (1990) Organizational socialization tactics: A longitudinal analysis of links to newcomers' commitment and role orientation. Acad Manag 33(4):847-858 
Ashforth BE, Sluss DM, Saks AM (2007) Socialization tactics, proactive behavior, and newcomer learning: integrating socialization models. J Vocat Behav 70(3):447-462

Brosig J, Heinrich T, Riechmann T, Schöb R, Weimann J (2010) Laying off or not? The influence of framing and economics education. Int Rev Econ Educ 9(1):44-55

Brown D, Brooks L (1996) Introduction to theories of career development and choice. In: Brown D, Brooks L (eds) Career choice and development, 3rd edn. Jossey-Bass, San Francisco, pp 1-30

Cipriani GP, Lubian D, Zago A (2009) Natural born economists? J Econ Psychol 30(3):455-468

Faravelli M (2007) How context matters: a survey based experiment on distributive justice. J Public Econ 91(7):1399-1422

Festinger L (1957) A theory of cognitive dissonance. Stanford University Press, Stanford

Floyd LA, Xu F, Atkins R, Caldwell C (2013) Ethical outcomes and business ethics: toward improving business ethics education. J Bus Ethics 117(4):753-776

Fotaki M, Prasad A (2015) Questioning neoliberal capitalism and economic inequality in business schools. Acad Manag Learn Educ 14(4):556-575

Frank RH (2013) Microeconomics and behavior. McGraw Hill, New York

Freie Universität Berlin (2012) Studienordnung für den Bachelorstudiengang Betriebswirtschaftslehre des Fachbereichs Wirtschaftswissenschaft der Freien Universität Berlin, Berlin

Frey BS, Pommerehne WW, Gygi B (1993) Economics indoctrination or selection? Some empirical results. J Econ Educ 24(3):271-281

Frey D, Dauenheimer D, Parge O, Haisch J (2001) Die Theorie sozialer Vergleichsprozesse. In: Frey D, Irle M (eds) Theorien der Sozialpsychologie, Band I: Kognitive Theorien, 2nd edn. Hans Huber, Bern, pp 81-121

Gibson R, Tanner C, Wagner AF (2016) Protected values and economic decision-making. In: Brosch T, Sander D (eds) Handbook of value-perspectives from economics, neuroscience, philosophy, psychology and sociology. Oxford University Press, Oxford, pp 223-242

Goossens A, Méon PG (2010) "This is an economist's argument!" The impact of studying economics, and other disciplines, on the belief that voluntary transactions make everyone better off. Working paper for the Silvaplana Workshop in Political Economy at the University of Cambridge. http:// www.solvay.edu/sites/upload/files/wp10012.pdf. Accessed 8 Aug 2018

Goossens A, Méon PG (2015) The belief that market transactions are mutually beneficial: a comparison of the views of students in economics and other disciplines. J Econ Educ 46(2):121-134

Gorman RF, Kehr JB (1992) Fairness as a constraint on profit seeking: comment. Am Econ Rev 82(1):355-358

Gruman JA, Saks AM, Zweig DI (2006) Organizational socialization tactics and newcomer proactive behaviors: an integrative study. J Vocat Behav 69(1):90-104

Guiso L, Sapienza P, Zingales L (2006) Does culture affect economic outcomes? J Econ Perspect 20(2):23-48

Hair JF, Hult GT, Ringle CM, Sarstedt M (2017) A primer on partial least squares structural equation modeling (PLS-SEM), 2nd edn. Sage, Thousand Oaks

Hair JF, Howard M, Nitzl C (2020) Assessing measurement model quality in PLS-SEM using confirmatory composite analysis. J Bus Res 109:101-110

Hambrick DC, Mason PA (1984) Upper Echelons: the organization as a reflection of its top managers. Acad Manag Rev 9(2):193-206

Haucap J, Just T (2003) Der Preis ist heiß. Aber warum? Der Einfluss des Ökonomiestudiums auf die Einschätzung der Fairness des Preissystems. Universität der Bundeswehr Hamburg/University of the Federal Armed Forces Hamburg, Fächergruppe Volkswirtschaftslehre/Department of Economics, Diskussionspapier Nr. 24, Hamburg

Haucap J, Just T (2010) Not guilty? Another look at the nature and nurture of economics. Eur J Law Econ 29(2):239-254

Heinrich CJ (2002) Outcomes-based performance management in the public sector. Implications for government accountability and effectiveness. Public Admin Rev 62(6):712-725

Holland JL (1997) Making vocational choices: a theory of vocational personalities and work environments, 3rd edn. Psychological Assessment Resources, Odessa

Hummel K, Pfaff D, Rost K (2018) Does economics and business education wash away moral judgment competence? J Bus Ethics 150(2):559-577

Jones GR (1986) Socialization tactics, self-efficacy, and newcomers' adjustments to organizations. Acad Manag J 29(2):262-279 
Kahneman D, Knetsch JL, Thaler R (1986a) Fairness as a constraint on profit seeking: entitlements in the market. Am Econ Rev 76(4):728-741

Kahneman D, Knetsch JL, Thaler R (1986b) Fairness and the assumptions of economics. J Bus 59(4):285-300

Katz R (2004) Organizational Socialization and the Reduction of Uncertainty. In: Katz R (ed) The human side of managing technological innovation: a collection of readings, 2nd edn. Oxford University Press, Oxford, pp 34-47

Korioth S (2006) Legal education in Germany today. Wis Int Law J 24(1):85-107

Kreisverwaltungsreferat der Landeshauptstadt München (2010) Parkraummanagement in München. Landeshauptstadt München, München

Kunz J, Linder S (2012) Organizational control and work effort-another look at the interplay of rewards and motivation. Eur Account Rev 21(3):591-621

Lanteri A, Rizzello S (2009) The economic way of thinking and the training of economists. Int J Soc Sci 3(2):161-168

Ludwig-Maximilians-Universität München (2016) Prüfungs- und Studienordnung der Ludwig-Maximilians-Universität München für den Bachelorstudiengang Betriebs-wirtschaftslehre (2015) Vom 18. März 2016. Ludwig-Maximilians-Universität München, München

Lüthje C (2008) Der Prozess der Innovation. Mohr Siebeck, Tübingen

McCabe D, Dukerich JM, Dutton J (1991) Context, values and moral dilemmas: comparing the choices of business and law school students. J Bus Ethics 10(12):951-960

McCabe D, Dukerich JM, Dutton J (1994) Values and the resolution of ethical dilemmas: business school vs. law school students. Journal of Business Ethics 13(9):693-700

Nauta MM (2013) Holland's theory of vocational choice and adjustment. In: Brown SD, Lent RW (eds) Career development and counseling: Putting theory and research to work, 2nd edn. Wiley, Hoboken, pp 55-82

Nitzl C (2016) The use of partial least squares structural equation modelling (PLS-SEM) in management accounting research: Directions for future theory development. J Account Lit 37:19-35

Nitzl C (2018) Management accounting and partial least squares-structural equation modelling (PLSSEM): some illustrative examples. In: Avkiran NK, Ringle CM (eds) Partial least squares structural equation modeling: recent advances in banking and finance. Springer, Cham, pp 211-229

Pascale RT (1985) The paradox of "corporate culture": reconciling ourselves to socialization. Calif Manag Rev 27(2):26-41

Personal- und Organisationsreferat der Landeshauptstadt München (2014) Übernahme des Personals des Textil-und Reinigungsservices (TRS) der Städtisches Klinikum München GmbH bei der Landeshauptstadt München. Landeshauptstadt München, München

Pfeffer J (1997) New directions for organization theory: problems and prospects. Oxford University Press, New York

Porter LW, Lawler EE, Hackmann JR (1975) Behavior in organizations. McGraw-Hill, New York

Raab-Steiner E, Benesch M (2018) Der Fragebogen: Von der Forschungsidee zur SPSS-Auswertung, 5th edn. Wien, UTB

Rainey HG, Pandey S, Bozeman B (1995) Research Note. Public and private managers' perceptions of red tape. Public Admin Rev 55:567-574

Rosengart T, Hirsch B, Nitzl C (2019) The effects of legal versus business education on decision making in public administrations with a Weberian tradition. Bus Res 12(2):455-478

Rubinstein A (2006) A sceptic's comment on the study of economics. Econ J 116(510):C1-C9

Saks AM, Ashforth BE (1997) Organizational socialization: making sense of the past and present as a prologue for the future. J Vocat Behav 51(2):234-279

Schein EH (2003) Organizational socialization and the profession of management. In: Porter LW, Angle HL, Allen RW (eds) Organizational influence processes. M.E. Sharpe, Armonk, pp 283-294

Sozialreferat der Landeshauptstadt München (2014) Grundsatzbeschluss zu Ausschreibung und Vergabe von städtischen Grundstücken für das Kommunale Wohnungsbauprogramm. Landeshauptstadt München, München

Spokane AR (1996) Holland's theory. In: Brown D, Brooks L (eds) Career choice and development, 3rd edn. Jossey-Bass, San Francisco, pp 33-74

Streukens S, Leroi-Werelds S (2016) PLS FAC-SEM: an illustrated step-by-step guideline to obtain a unique insight in factorial fata. Ind Manag Data Syst 116(9):1922-1945

Taylor BJ (2006) Factorial surveys: using vignettes to study professional judgment. Br J Soc Work 36(7):1187-1207 
Walker RM, Brewer GA, Bozeman B, Moon MJ, Wu J (2013) An experimental assessment of public ownership and performance. Comparing perceptions in East Asia and the United States. Public Manag Rev 15(8):1208-1228

Wallander L (2009) 25 Years of factorial surveys in sociology: a review. Soc Sci Res 38(3):505-520

Wang L, Malhotra D, Murnighan JK (2011) Economics education and greed. Acad Manag Learn Educ 10(4):643-660

Wilkins KG, Tracey TJ (2014) Person environment fit and vocational outcomes. In: Coetzee M (ed) Psychosocial career meta-capacities_dynamics of contemporary career development. Springer, Cham, pp 123-138

Wolff V (2017) Diese Jobchancen haben Juristen mit schlechten Examensnoten. https://www.spiegel.de/ lebenundlernen/uni/jurastudium-jobchancen-fuer-juristen-mit-schlechten-examensnoten-a-11638 36.html. Accessed 2 Feb 2020

Wood M (2005) Bootstrapped confidence intervals as an approach to statistical inference. Org Res Methods 8(4):454-470

Publisher's Note Springer Nature remains neutral with regard to jurisdictional claims in published maps and institutional affiliations. 